\title{
Authentic Arseholes and the Problem with Transformational Leaders
}

\author{
John P. Mills \\ ${ }^{1}$ University of Essex, School of Sport, Rehabilitation, and Exercise Sciences, Wivenhoe \\ Park, Colchester, Essex, CO34SQ, United Kingdom \\ Corresponding Author: johnp.mills@outlook.com
}




\begin{abstract}
Within the present manuscript, I outline some of the problems associated with the labels used within the transformational leadership literature. To do this, I briefly discuss transformational leadership as a concept, identify gaps in our current empirical understanding of the concept, clarify a host of conceptual issues, and suggest some initial ideas around how we as a field may attend to measurement problems that have hampered the advancement of research examining transformational leadership at more than a behavioral level. Specifically, I critically challenge (1) use of the term authentic transformational leadership, and (2) definitions of transformational leaders. It is hoped that in clarifying these misconceptions, the field may be able to advance more clearly in its collective use of language.
\end{abstract}




\section{Authentic Arseholes and the Problem with Transformational Leaders}

Transformational leadership has gained worldwide notoriety since James McGregor Burns wrote his seminal text 'Leadership' in 1978. Academic research in the topic intensified in the mid-1980s when Bernard Bass operationalized Burns' theory (Bass, 1985), with somewhere in the region of 140,000 manuscripts examining transformational leadership having been generated to date. Despite more than four decades passing and proliferating many alternate approaches to leadership, the number of manuscripts produced that examine transformational leadership continues to rise year-on year. However, as Transformational leadership has grown in popularity, various conceptual inaccuracies have become embedded within the literature. Within this manuscript, I discuss the problem with inaccurate terminology and use two examples to illustrate this point. I first identify problems with the term authentic transformational leadership, before then arguing that there is little basis to the frequently used term 'transformational leader'.

\section{Transformational Leadership}

According to Burns (1978, p. 19) leadership is defined as "inducing followers to act for certain goals that represent the values and motivations - the wants and needs, the aspirations and expectations - of both leaders and followers". Further, transformational leadership seeks to "raise the level of human conduct and ethical aspiration of both the leader and led, and thus it has a transforming effect on both" (ibid, p.20). The result of transformational leadership, then, is a "relationship of mutual stimulation and elevation that converts followers into leaders and may convert leaders into moral agents" (Burns, 1978, p. 4). In essence, transformational leadership is the process of co-constructing beliefs, goals, and values that motivate both the leader and the follower to strive for excellence (Bass \& Riggio, 2012; Burns, 1978; Yukl, 1999).

Transformational leadership behaviours are not a toolkit to be selectively employed in an attempt to control or manipulate others (Mills \& Boardley, 2016). They are a set of behaviors that have been identified as creating a reciprocal understanding between a leader and their followers (Burns, 1978). By working together, leaders and followers ought to surpass individual interests and raise each other's levels of motivation and mortality (Burns, 1978). Rather than controlling their followers, leaders who display these behaviors generate symbolic power by creating and communicating an idealistic and shared vision for the future (Bass \& Riggio, 2012). At a practical level, this is achieved by expressing clear expectations, differentiating tasks to stimulate and consider followers' needs, and coaching followers to achieve the group's shared goals. 
They inspire, motivate, and intellectually stimulate those who follow through their words and actions; challenging those who follow to think creatively, solve problems, and achieve (Bass and Riggio, 2012). Leaders should also take an interest in those who follow and get to know them as people in order to be individually considerate of their needs. All the while doing so in a consistent and authentic manner (Price, 2017).

\section{Authentic Arseholes}

Although Burns (1978) and Bass (1985) agreed on the influence transformational leadership can exert, they disagreed over whether leaders who lacked character could ever truly garner the positive effects associated with the aforementioned behaviors. Burns (1978) proposed that only leaders of character (i.e., true transformational leadership) could advance followers towards self-sacrifice for the greater good. For Burns (1978, p. 36) "leadership is a process of morality to the degree that leaders engage with followers on the basis of shared motives, values, and goals". As such, he did not believe that those who lack character could demonstrate transformational qualities. Bass (1985), however, disagreed and instead suggested that the issue of motive be used to distinguish between authentic and pseudo-transformational leadership. Bass and Steidlmeier (1999) would later go on to develop a conceptual framework around the notion of authentic and pseudo-transformational leadership, which would place motive, character, and self-presentation at the heart of transformational leadership.

Although Bass and many others refer to Authentic-Transformational Leadership (Barling, Christie, \& Turner, 2008; Bass \& Steidlmeier, 1999; Christie, Barling, \& Turner, 2011; Price, 2003), for us and Dasborough and Ashkanasy (2002), this creates an unnecessary level of confusion. Although Bass and Steidlmeier (1999) clearly state that they refer to authentic as meaning genuine or real (as opposed to false or fake), scholars such as Avolio and Gardner (2005) take this as meaning true to oneself. Similarly, Harter, Schmidt, and Hayes (2002, p.382) describe authenticity as "owning one's personal experiences, be they thoughts, emotions, needs, preferences, or beliefs, processes captured by the injunction to know oneself". Given this definition, I do not believe authenticity can be accurately applied within the context of distinguishing between the different ends of the transformational leadership continuum. To behave in an authentic manner, means it is perfectly possible to know and own one's base tendencies (see Price, 2003). This creates an irreconcilable juxtaposition within the transformational leadership and as such, I adopt and advocate the less used, but arguably clearer terminology of true-transformational leadership.

Individuals who possess true transformational leadership tendencies are described as being value centered (Bass \& Steidlmeier, 1999), referent with power, altruistic (Kanungo \& Mendonca, 1996), and being committed to assisting their 
followers' development; even when this means they are required to transcend their own egoistic desires (Avolio \& Gardner, 2005). Such leaders tend to be morally uplifting (Burns, 1978), liberating (Carey, 1992), and empowering (Price, 2003). They understand themselves and their values and are perceived as considerate of the values of their followers. Subsequently, they use this understanding to create an idealized and ethical vision for the future, based upon evolving perceptions of mutual trust and respect between leader and follower[s] (Fairholm, 2009). True transformational leadership, then, shares many similarities with more servant forms of leadership (Gillet, Cartwright, \& van Hugt, 2011). Ultimately, true transformational leadership is characterised by selfless intentions, personal integrity (i.e., consistency in words and actions), and virtuous behaviour -- such as working for the greater good (Bass, 1985). As such, those who possess true transformational tendencies to align with the notion of being individuals of character, regardless of whether they are viewed in terms of their characteristics, outcomes stemming from their actions, or the mechanisms through which they create these outcomes (Bass \& Steidlmeier, 1999).

In contrast, pseudo-transformational leadership is associated with a lack of character and is described as manipulative, abusive, unethical, immoral, controlling, and egoistic (Barling et al., 2008; Bass \& Steidlmeier, 1999; Choi, 2006; Dasborough \& Ashkanasy, 2002; Price, 2003). However, depending on the success of the leader's tactical impression management (e.g., outcome-contingent rewards, normative comparisons, and contingent affection; Bartholomew, Ntoumanis, Thøgersen-Ntoumani., 2009) the follower may not realize that they have been manipulated, abused or controlled until after the event (Matosic et al., 2015). Further, pseudo-transformational leadership is related to the promotion of dependency and the shared internalization of immoral standards (Ferris Ferris, Bhawuk, Fedor, \& Judge, 1995). Although through the use of self-presentation it may appear otherwise, those who possess pseudo-transformational leadership tendencies have little empathy or regard for those who follow them (Simola, Barling, \& Turner, 2010). Instead, followers are simply a means to help them achieve their egoistic ends (Price, 2003). However, as Dasborough and Ashkanasy (2002) point out, at a behavioral level and up until the moment that deception is identified, true and pseudo-transformational leadership may appear as two sides of the same coin.

Naber and Moffett (2017) recently argued that true and pseudo-transformational leadership are "unique style[s] of leadership". I disagree on the basis that both true and pseudo-transformational leadership use the same transformational leadership behaviors (Dasborough \& Ashkanasy, 2002). Although very few scholars define what is meant when they use the term 'leadership style', Hersey and Blanchard's (1982) definition as a consistent pattern of behavior that a leader uses when working with and through people is a reasonable summation. Within this context 
then, it is difficult to see how true and pseudo-transformational leadership would differ on existing measures of transformational leadership behaviours. Price's (2003) conceptualization of pseudo-transformational leadership is largely dependent on the desire and efficacy one has to self-present and whether the self-presentation attempt is successful.

Although there have been novel attempts to use reaction time tasks to examine associations and limit the influence of self-presentation strategies during leadership assessments (see Mills \& Boardley, 2017), no measure is fully resistant to the types of manipulation and deception that defines pseudo-transformational leadership. If viewed as distinct leadership styles and evaluated on behavioural outcomes, researchers would likely need to covertly examine a combination of character (Bass \& Steidlmeier, 1999), self-presentation effectiveness (Price, 2003), or an interaction between the two over a longitudinal period and in relation to existing measures of transformational leadership behaviour. I appreciate the challenges in conducting such research, but as transformational leadership matures as a concept, I implore leadership scholars to rise to the challenge and attend to this call to action.

\section{The Problem with Transformational Leaders}

For Burns' (1978, p.4), the founding father of transformational leadership, transforming leaders are those who "look for potential motives in followers, seek to satisfy higher needs, and engage the full person of the follower" (Burns, 1978, p. 4). Similarly, Bass (1985, p.17), defines transformational leaders as those who: "attempt and succeed in raising colleagues, subordinates, followers, clients, or constituencies to greater awareness about the issues of consequence. This heightening of awareness requires a leader with vision, self-confidence, and inner strength to argue successfully for what he [sic] sees is right or good, not for what is popular or is acceptable according to established wisdom of the time".

Here Burns is careful in his use of language, using the verb transforming rather than the adjective transformational. Although subtle, the difference in these terms is important. Transforming suggests an ongoing process, whereas transformational describes an attribute. Transforming is participatory, whereas transformational describes a state of being (Wren, 1995). It is such language that makes those who are interested in the leader-member exchange or leader-follower relationships more broadly believe that transformational leadership is a one-way process, but for Burns it was far more interactional. Although not discussed within the literature, Burns' focus on process rather than outcome may also explain why he views morality as a requirement of transforming leaders, whilst Bass did not. This disagreement is an issue of moral philosophy and in particular normative ethics. Burn's view is more aligned to 
deontology and the ongoing duty of the leader to raise their followers, whereas Bass is more associated with utilitarianism.

Putting semantics to one side, neither definition is captured within the dimensions of either of the dominant measures of transformational leadership. The label of transformational leader, then, has since been misused tens of thousands of times to describe those who score highly on a questionnaire (e.g., Multifactor Leadership Questionnaire [Bass \& Avolio, 2000] or the Transformational Leadership Inventory [Podsakoff et al., 1990]). At the time of writing (February 2020), Google Scholar reports some 24,700 manuscripts within their database that use the phrase 'Transformational Leader' between 1978-2020. A search of the Europe PMC database for usage trends overtime, reports 22,608 instances within the same period (see figure 1). This is problematic for a number of reasons. First, there is no consensus between leadership scholars as to the quantity of behaviours required, the frequency in which a behaviour needs to be observed, or the number of people who need to agree in order to bestow the title of transformational leader (Mills \& Boardley, 2016; Hardy et al., 2010). Second, classifying and labeling people simplifies a complex process. One cannot simply complete a self-report questionnaire and deem themselves transformational (Mills \& Boardley, 2017). Transformation is a process. There is no end point, just progression and regression. I therefore implore leadership scholars to take caution in their use of language. Whilst many reading this may believe these subtle differences are pedantic, accuracy of language is important. If transformational leadership is to mature as a construct, clarifying such inaccuracies will be important. Alas, as Kelley (1927) pointed out nearly 100 years ago, such inaccuracies contaminate clear thinking and may lead to the type of construct proliferation that has plagued our field (Shaffer, DeGeest, \& Li, 2015). 


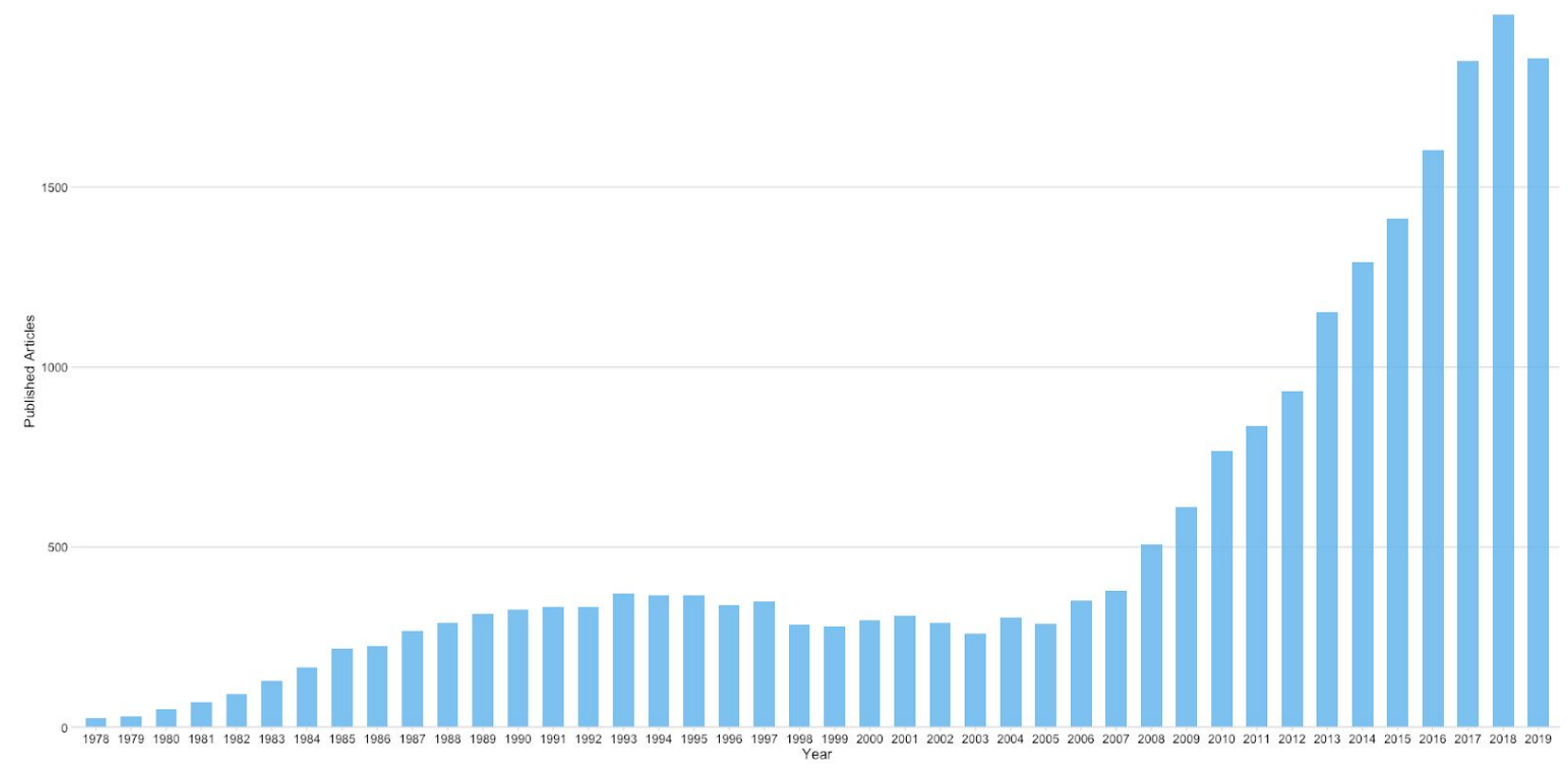

Figure 1. Total reported use of the term 'transformational leader' between 1978-2019

\section{Conclusion}

Within the present manuscript, I identify problems with the term authentic transformational leadership and critically challenge use of the term transformational leader. I then argue that there is little basis to the frequently used term 'transformational leader' and argue that given the current discrepancies between the way the term is defined and operationalised, use of the term should be limited to describing an ideological position. Leaders may demonstrate leadership behaviour, but doing so does not forever assign a label; be it transformational, transactional, ethical, authentic or any number of alternatives. Leading is dynamic -- the behaviours associated with various leadership styles are considerably less so. To use a slightly flippant analogy, if one walks down the road waddling and quaking, passersby do not say "look there is a duck" but rather "look there is a person behaving like a duck". Demonstrating a behaviour or series of behaviours is not enough to confer a title.

Transformation is beautiful, fluid, and ultimately unending. Much in the same way as a reformed criminal or addict takes one day at a time in transforming their life, so do the people supporting that change. Demonstrating leadership is the same and labels like transformational leader undermine the process. As the study of transformational leadership continues to grow and it is my hope that this manuscript creates a point for scholars to point to when educating young researchers. It is also hoped that this manuscript goes some way in stemming the tide of misused terms 
within the literature and helps to increase conceptual clarity around commonly used terms. 


\section{References}

Avolio, B. J., \& Gardner, W. L. (2005). Authentic leadership development: Getting to the root of positive forms of leadership. The Leadership Quarterly, 16(3), 315-338. https://doi.org/10.1016/j.leaqua.2005.03.001

Barling, J., Christie, A., \& Turner, N. (2008). Pseudo-Transformational Leadership: Towards the Development and Test of a Model. Journal of Business Ethics: JBE, 81(4), 851-861. https://doi.org/10.1007/s10551-007-9552-8

Bartholomew, K. J., Ntoumanis, N., \& Thøgersen-Ntoumani, C. (2009). A review of controlling motivational strategies from a self-determination theory perspective: Implications for sports coaches. International Review of Sport and Exercise Psychology, 2, 215-233. doi: 10.1080/17509840903235330

Bass, B. M. (1985). Leadership and performance beyond expectations. Retrieved from http://agris.fao.org/agris-search/search.do?recordID=US201300430719

Bass, B. M., \& Avolio, B. J. (2000). MLQ Multifactor Leadership Questionnaire Redwood City: Mind Garden.

Bass, B. M., \& Riggio, R. E. (2012). Transformational Leadership. Psychology Press. Retrieved from https://market.android.com/details?id=book-2WsJSw6wa6cC

Bass, B. M., \& Steidlmeier, P. (1999). Ethics, character, and authentic transformational leadership behavior. The Leadership Quarterly, 10(2), 181-217. https://doi.org/10.1016/s1048-9843(99)00016-8

Burns, J. M. (1978). Leadership. NY. Harper \& Row.

Carey, M.R. (1992) Transformational leadership and the fundamental option for self-transcendence. The Leadership Quarterly, 3(3). 217-236.

Christie, A., Barling, J., \& Turner, N. (2011). Pseudo-Transformational Leadership: Model Specification and Outcomes1. Journal of Applied Social Psychology, 41(12), 2943-2984. https://doi.org/10.1111/j.1559-1816.2011.00858.x

Choi, J. (2006). A motivational theory of charismatic leadership: Envisioning, empathy, and empowerment. Journal of Leadership \& Organizational Studies, 13(1), 24-43. Retrieved from http://journals.sagepub.com/doi/abs/10.1177/10717919070130010501

Dasborough, M. T., \& Ashkanasy, N. M. (2002). Emotion and attribution of intentionality in leader-member relationships. The Leadership Quarterly, 13(5), 615-634. https://doi.org/10.1016/s1048-9843(02)00147-9 
Fairholm, M. R. (2009). Leadership and Organizational Strategy. The Innovation Journal: The Public Sector Innovation Journal, 14(1), 1-16.

Ferris, G. R., Bhawuk, D., Fedor, D. F., \& Judge, T. A. (1995). Organizational politics and citizenship: Attributions of intentionality and construct definition. Advances in Attribution Theory: An Organizational Perspective, 231-252.

Gillet, J., Cartwright, E., \& Vugt, M. (2011). Selfish or servant leadership? Evolutionary predictions on leadership personalities in coordination games. Personality and Individual Differences, 51, 231-236.

Hardy, L., Arthur, C.A., Jones, G., Shariff, A., Munnoch, K., Isaacs, I., \& Allsopp, A.J. (2010). The relationship between transformational leadership behaviors, psychological, and training outcomes in elite military recruits. Leadership Quarterly, 21, 20-32.

Harter, J. K., Schmidt, F. L., \& Hayes, T.L. (2002). Business-unit-level relationship between employee satisfaction, employee engagement, and business outcomes: A meta-analysis. Journal of Applied Psychology, 87, 268-279.

Hersey, P., \& Blanchard, K. H. (1982). Leadership style: Attitudes and behaviors. Training \& Development Journal, 36(5), 50-52.

Kanungo, R. N., \& Mendonca, M. (1996). Ethical dimensions of leadership. London: Sage.

Kelly, T.L. (1927). Interpretation of Educational Measurements. Yonkers, New York: World Book Company. 62-65.

Matosic, D., Ntoumanis, N., Boardley, I. D., Sedikides, C., Stewart, B. D., \& Chatzisarantis, N. (2015). Narcissism and coach interpersonal style: A self-determination theory perspective. Scandinavian Journal of Medicine \& Science in Sports. https://doi.org/10.1111/sms.12635

Mills, J. P., \& Boardley, I. D. (2016). Advancing leadership in sport: Time to 'actually' take the blinkers off? Sports Medicine. Retrieved from http://eprints.chi.ac.uk/2008/

Mills, J. P., \& Boardley, I. D. (2017). Development and initial validation of an indirect measure of transformational leadership integrity. Psychology of Sport and Exercise, 32,34-46

Naber, A. M., \& Moffett, R. G. (2017). Moral Reasoning Ability and the Perception of Transformational Leadership. Journal of Applied Social Psychology, 47(2), 99-112. https://doi.org/10.1111/jasp.12427

Podsakoff, M., Mackenzie, S. B., \& Moorman, H. (1990). Leader behaviors and their effects on followers' trust in leader, satisfaction, and citizenship behaviors. The Leadership Quarterly, 1(2), 107-142. 
Price, T. L. (2003). The ethics of authentic transformational leadership. The Leadership Quarterly, 14(1), 67-81. https://doi.org/10.1016/S1048-9843(02)00187-X

Price, T. (2017). A "critical leadership ethics" approach to the Ethical Leadership construct. Leadership. https://doi.org/10.1177/1742715017710646

Schaffer, J. A., DeGeest, D., \& Li, A. (2015). Tackling the Problem of Construct Proliferation: A Guide to Assessing the Discriminant Validity of Conceptually Related Constructs. Organizational Research Methods, 19(1), 80-110.

Simola, S. K., Barling, J., \& Turner, N. (2010). Transformational leadership and leader moral orientation: Contrasting an ethic of justice and an ethic of care. The Leadership Quarterly, 21(1), 179-188.

https://doi.org/10.1016/j.leaqua.2009.10.013

Wren, J. T. (Ed.). (1995). The leader's companion: Insights on leadership through the ages. New York: Free Press.

Yukl, G. (1999). An evaluation of conceptual weaknesses in transformational and charismatic leadership theories. The Leadership Quarterly, 10(2), 285-305. https://doi.org/10.1016/s1048-9843(99)00013-2 